\title{
PENGARUH PENGETAHUAN PERPAJAKAN, TINGKAT PENDIDIKAN, DAN \\ SANKSI ADMINISTRASI TERHADAP KEPATUHAN WAJIB PAJAK DALAM \\ MELAKUKAN PEMBAYARAN PAJAK BUMI DAN BANGUNAN (Studi Kasus Pada Kantor Dinas Pendapatan Daerah Kabupaten Sleman)
}

\author{
Tika Wulandari* \\ Suyanto \\ Program Studi Akuntansi Fakultas Ekonomi \\ Universitas Sarjanawiyata Tamansiswa \\ *wtika46@yahoo.com
}

\begin{abstract}
This study aims to determine the factors that influence compliance in land and building tax payments in the District Sleman.Variabel dependent adherence in this study were paying taxes. The independent variables in this study include knowledge of taxation, education, administrative sanctions. This study used a questionnaire for data collection. Sample research study is registered taxpayers in Revenue Kabupten Sleman.

Analysis of research data using multiple linear regression. The results showed that the variable tax knowledge and administrative penalties positive significant effect on adherence Land And Building Tax payments while the education variable does not affect the compliance of land and building tax payments.
\end{abstract}

Keywords: knowledge of taxation, education, administrative sanctions, Compliance.

\section{PENDAHULUAN}

Salah satu fungsi pajak adalah sumber keuangan negara (Budgetair) yaitu sebagai sumber penerimaan negara yang digunakan untuk membiayai seluruh pengeluaran rutin maupun pembangunan negara (Tjahjono, 2005). Pajak merupakan pungutan negara yang tidak memberikan balas jasa secara langsung, sifatnya mengikat dan dapat dipaksakan, yang digunakan untuk kemakmuran rakyat. (Tjahjono, 2005). Kepatuhan wajib pajak dapat menjadi salah satu kendala yang dapat menghambat keefektifan pengumpulan pajak. Kepatuhan wajib pajak dapat didefinisikan sebagai suatu sikap/perilaku seorang wajib pajak yang melaksanakan semua kewajiban perpajakannya dan menikmati semua hak perpajakannya sesuai dengan ketentuan peraturan perundangan yang berlaku (Nurmantu, 2009 dalam Putri, 2013). Pengertian Pajak Bumi dan Bangunan menurut Perda Kabupaten Sleman Nomor 11
Tahun 2012 Pasal 1 tentang Pajak Bumi dan Bangunan Pedesaan dan Perkotaan adalah pajak atas bumi dan bangunan yang dimiliki, dikuasai yang dimiliki, dikuasai, dan atau dimanfaatkan oleh orang pribadi atau badan, kecuali kawasan yang digunakan untuk kegiatan usaha perkebunan, perhutanan dan pertambangan

Banyak faktor yang mempengaruhi tingkat kepatuhan pembayaran Pajak Bumi dan Bangunan, antara lain pengetahuan perpajakan, pendidikan dan sanksi administrasi. Pengetahuan perpajakan mengenai konsep ketentuan umum di bidang perpajakan, jenis pajak yang berlaku di Indonesia mulai dari subyek pajak, obyek pajak, tarif pajak, adalah pengetahuan perhitungan pajak terutang, pencatatan pajak terutang, sampai dengan bagaimana pengisian pelaporan pajak (Supriyati, 2009). Pendidikan pada dasarnya merupakan usaha pengembangan sumber daya manusia yang dilakukan secara sistematis, pragmatis dan 
berjenjang agar menghasilkan manusiamanusia yang berkualitas yang dapat memberikan manfaat dan sekaligus meningkatkan harkat dan martabatnya (Istanto, 2010). Tingkat pendidikan masyarakat yang semakin tinggi akan menyebabkan masyarakat semakin mudah memahami ketentuan dan peraturan perundang-undangan di bidang perpajakan yang berlaku. Mardiasmo (2011) menyatakan bahwa Sanksi perpajakan merupakan jaminan bahwa ketentuan peraturan perundang-undangan perpajakan (norma perpajakan) akan dituruti/ditaati/dipatuhi.

Berdasarkan kondisi yang telah dipaparkan, memberikan motivasi untuk dilakukannya penelitian dan analisis beberapa faktor yang mempengaruhi kepatuhan wajib pajak dengan judul " Pengaruh Pengetahuan Perpajakan, Pendidikan, dan Sanksi Administrasi terhadap kepatuhan Wajib Pajak dalam melakukan pembayaran Pajak Bumi dan

Berdasarkan permasalahan yang tertulis dalam latar belakang di atas, maka perumusan masalah dinyatakan dalam pertanyaan sebagai berikut: (1) Apakah pengetahuan wajib pajak tentang perpajakan berpengaruh terhadap tingkat kepatuhan pembayaran Pajak Bumi dan Bangunan di Kabupaten Sleman?

(2) Apakah tingkat pendidikan berpengaruh terhadap tingkat kepatuhan pembayaran Pajak Bumi dan Bangunan di Kabupaten Sleman? (3) Apakah sanksi administrasi yang diterapkan berpengaruh terhadap tingkat kepatuhan pembayaran Pajak Bumi dan Bangunan di Kabupaten Sleman? (4) Apakah faktor pengetahuan, SPPT atau sanksi administrasi yang paling berpengaruh terhadap tingkat kepatuhan pembayaran $\mathrm{PBB}$ ?

\section{LANDASAN TEORI PENGETAHUAN PERPAJAKAN}

Pengetahuan adalah sesuatu yang diketahui berkaitan dengan proses pembelajaran. Proses belajar ini dipengaruhi berbagai faktor dari dalam seperti motivasi dan faktor luar berupa sarana informasi yang tersedia serta keadaan sosial budaya (Kamus Besar Bahasa Indonesia, 2003). Secara garis besar menurut tingkat pengetahuan mempunyai enam tingkatan, meliputi: mengetahui, memahami, menggunakan, menguraikan, menyimpulkan dan mengevaluasi. Ciri pokok dalam taraf pengetahuan adalah ingatan tentang sesuatu yang diketahuinya baik melalui pengalaman, belajar, ataupun informasi yang diterima dari orang lain.

Berdasarkan uraian-uraian di atas, maka dapat kita definisikan bahwa pengetahuan merupakan hasil dari proses mencari tahu. Dalam proses mencari tahu ini mencakup berbagai metode dan konsep-konsep, baik melalui proses pendidikan maupun melalui pengalaman. Dengan adanya pemahaman yang benar mengenai pajak,diharapkan dapat meningkatkan kepatuhan wajib pajak untuk melaksanak kewajiban sebagai warga negara dengan membayar pajak tepat waktu.

Pengetahuan perpajakan mengenai konsep ketentuan umum di bidang perpajakan, jenis pajak yang berlaku di Indonesia mulai dari subyek pajak, obyek pajak, tarif pajak, adalah pengetahuan perhitungan pajak terutang, pencatatan pajak terutang, sampai dengan bagaimana pengisian pelaporan pajak. Pengetahuan perpajakan ini tidak hanya pemahaman konseptual berdasarkan Undang-Undang Perpajakan, Keputusan Menteri Keuangan, Surat Edaran, Surat keputusan tetapi juga adanya tuntutan kemampuan atau ketrampilan teknis bagaimana menghitung besarnya pajak yang terutang (Supriyati, 2009).

Pengetahuan pajak merupakan sesuatu yang penting untuk dimiliki oleh wajib pajak. Apabila wajib pajak sadar dan mengetahui mengenai arti penting, manfaat dan tujuan dari pembayaran pajak yang dilakukan kepada negara, maka wajib pajak dengan sukarela melakukan pembayaran pajak secara tertib dan tepat waktu. Pengetahuan dapat berasal dari pemahaman 
undang-undang perpajakan, sosialisasi media televisi, media cetak maupun penyuluhan yang dilakukan oleh pejabat pajak maupun pejabat desa. Pengetahuan tentang perpajakan juga dapat diperoleh dari bidang pendidikan formal maupun informal. Berdasarkan penelitian yang dilakukan sebelumnya menunjukkan hasil yang tidak signifikan, maka penulis merumuskan hipotesis sebagi berikut:

H1 : Pengetahuan wajib pajak berpengaruh positif terhadap tingkat kepatuhan pembayaran Pajak Bumi dan Bangunan.

\section{PENDIDIKAN}

Saat ini pendidikan di Indonesia sudah menjadi suatu kewajiban dalam rangka meningkatkan sumber daya masyarakat Indonesia. Pendidikan merupakan hal yang sangat penting sehingga tidak terlepas dari kehidupan sehari-hari. Menurut Hasan (2005) dalam Istanto (2010), pendidikan pada dasarnya merupakan usaha pengembangan sumber daya manusia yang dilakukan secara sistematis, pragmatis dan berjenjang agar menghasilkan manusiamanusia yang berkualitas yang dapat memberikan manfaat dan sekaligus meningkatkan harkat dan martabatnya. Peningkatan kualitas diri manusia yang dicapai melalui pendidikan diharapkan dapat mencakup beberapa aspek antara lain: (a) Peningkatan kualitas fikir (kecerdasan, kemampuan analisis, kreatifitas, dan visioner), (b) Peningkatan kualitas moral (ketakwaan, kejujuran, ketabahan, keadilan dan tanggung jawab), (c) Peningkatan kualitas kerja (ketrampilan, professional, dan efisien), (d) Peningkatan kualitas hidup (kesejahteraan materi dan rohani, ketentraman dan terlindungnya martabat dan harga diri)

- Seseorang yang mendapatkan pendidikan lebih tinggi, akan lebih tinggi pula status sosial ekonominya dalam kehidupan masyarakat. Karena dengan bekal yang telah diperoleh seseorang dari lembaga pendidikan yang pernah dimasuki secara tidak langsung dapat membuka pintu ilmu pengetahuan dan ketrampilan yang sangat bermanfaat bagi kelangsungan hidup individual maupun sosial.

Berdasarkan kesimpulan diatas dapat kita lihat bahwa semakin tinggi tingkat pendidikan seseorang biasanya semakin tinggi pula tingkat kepatuhan seseorang untuk melaksanakan kewajiban membayar pajaknya. Maka penulis merumuskan hipotesis sebgai berikut:

H2: Tingkat Pendidikan berpengaruh positif terhadap tingkat kepatuhan pembayaran Pajak Bumi dan Bangunan.

\section{SANKSI ADMINISTRASI}

Landasan hukum mengenai sanksi perpajakan diatur dalam masing-masing pasal Undang-Undang Ketentuan Umum Perpajakan. Sanksi perpajakan dapat dijatuhkan apabila wajib pajak melakukan pelanggaran terutama atas kewajiban yang ditentukan dalam Undang-Undang Ketentuan Umum Perpajakan. Mardiasmo (2011) menyatakan bahwa Sanksi perpajakan merupakan jaminan bahwa ketentuan peraturan perundang-undangan perpajakan (norma perpajakan) akan dituruti/ditaati/dipatuhi. Dengan kata lain sanksi perpajakan merupakan alat pencegah agar Wajib Pajak tidak melanggar norma perpajakan.

Dalam Undang-Undang Perpajakan dikenal dua macam sanksi yaitu Sanksi Administrasi dan Sanksi Pidana. Bagi para pelanggar suatu norma perpajakan ada yang diancam dengan sanksi administrasi saja atau sanksi pidana saja bahkan ada pula yang diancam sanksi administrasi dan pidana. Sanksi pidana merupakan siksaan atau penderitaan yang digunakan fiskus sebagai alat terakhir atau benteng hukum yang digunakan fiskus sebagai alat terakhir atau benteng hukum yang digunakan fiskus agar norma perpajakan dipatuhi.

Ketentuan sanksi pidana diatur dalam Perda kabupaten Sleman Tahun 2012 pasal 34 ayat 1 yang berbunyi: Wajib pajak yang karena kealpaannya tidak menyampaikan SPOP sebagaimana dimaksud dalam Pasal 13 ayat (2) atau mengisi dengan tidak benar 
atau tidak lengkap atau melampirkan keterangan yang tidak benar sehingga merugikan keuangan Daerah dapat dipidana dengan pidana kurungan paling lama 1 (satu) tahun atau pidana denda paling banyak 2 (dua) kali jumlah pajak terutang yang tidak atau kurang dibayar.

Pasal 34 ayat 2 berbunyi : Wajib pajak yang dengan sengaja tidak menyampaikan SPOP sebagaimana dimaksud dalam Pasal 13 ayat (2) atau mengisi dengan tidak benar atau tidak lengkap atau melampirkan keterangan yang tidak benar sehingga merugikan keuangan Daerah dapat dipidana dengan pidana penjara paling lama 2 (dua) tahun atau pidana denda paling banyak 4 (empat) kali jumlah pajak terutang yang tidak atau kurang dibayar.

Sanksi administrasi terdiri dari tiga jenis sanksi administrasi yaitu sanksi administrasi berupa denda, sanksi administrasi berupa bunga, dan sanksi administrasi berupa kenaikan. Besaran denda dapat ditetapkan sebesar jumlah tertentu, persentase dari jumlah tertentu, atau suatu angka perkalian dari jumlah tertentu. Sanksi administrasi berupa bunga dikenakan atas pelanggaran yang menyebabkan utang pajak menjadi lebih besar. Jumlah bunga dihitung berdasarkan persentase tertentu dari suatu jumlah, mulai dari saat bunga itu menjadi hak/kewajiban sampai dengan saat diterima dibayarkan. Sanksi Administrasi berupa kenaikan adalah sanksi yang paling ditakuti oleh wajib Pajak. Hal ini karena bila dikenakan sanksi tersebut, jumlah pajak yang harus dibayar bisa menjadi berlipat ganda. Sanksi berupa kenaikan pada dasarnya dihitung dengan angka persentase tertentu dari jumlah pajak yang tidak kurang dibayar. Penelitian mengenai pengaruh sanksi administrasi sudah diteliti oleh penelitipeneliti sebelumnya namun hasil tidak konsisten, maka penulis merumuskan hipotesis sebagai berikut :

H3: Sanksi Administrasi berpengaruh positif terhadap tingkat kepatuhan pembayaran Pajak Bumi dan Bangunan

\section{METODE PENELITIAN}

Penelitian ini merupakan penelitian kuantitatif yaitu penelitian yang menggunakan pengukuran kuantitatif untuk menguji hipotesis dengan tujuan menemukan generalisasi dan menekankan pada pengukuran dan analisis hubungan sebab akibat antara variabel (Sekaran, 2000 dalam Sutari, 2013). Penelitian ini menganalisis tentang pengaruh pengetahuan, tingkat pendidikan dan sanksi perpajakan terhadap kepatuhan pembayaran Pajak Bumi dan Bangunan di Kabupaten Sleman.

\section{Populasi, Sampel dan Teknik Pengambilan Sampel}

Populasi yang digunakan dalam penelitian ini adalah semua wajib pajak yang dikenakan Pajak Bumi dan Bangunan di daerah Kabupaten Sleman. Adapun sampel yang digunakan oleh peneliti adalah wajib Pajak Bumi dan Bangunan yang ditemui di Kantor Dinas Pendapatan Daerah Kabupaten Sleman.

Teknik pengambilan sampel dalam penelitian ini menggunakan convenince sampling (sampling kemudahan), merupakan teknik pengambilan sampel yang diambil secara spontanitas artinya siapa saja yang secara tidak sengaja ketemu dan sesuai dengan karakteristiknya, maka orang tersebut dapat dijadikan sampel.

\section{Pengembangan Instrumen Penelitian}

Penelitian ini menggunakan kuesioner untuk mengukur variabel independen dan variabel dependen. Kuesioner yang digunakan menggunakan pengukuran skala likert 5 (lima) poin. Penelitian ini menggunakan pilot test atau uji awal penelitian sebelum penelitian yang sebenarnya. Pilot test tersebut mempunyai tujuan untuk meyakinkan item kuesioner telah mencukupi dan benar menurut responden. Kuesioner pilot test dalam penelitian ini disebar kepada 30 responden yang terdiri dari mahasiswa Universitas Sarjanawiyata Tamansiswa pada tanggal 24 Januari 2013 . 
Metode Analisis

\section{Uji Reliabilitas dan uji validitas}

Uji reliabilitas adalah pengujian untuk mengukur suatu kuesioner yang merupakan indikator dari variabel . Suatu kuesioner dikatakan reliabel atau handal jika jawaban seseorang terhadap pertanyaan konsisten atau stabil dari waktu ke waktu. Suatu kostruk atau variabel dikatakan reliabel jika memberikan nilai Cronbach Alpha > 0,60 (Ghozali, 2011).

Suatu kuisioner dinyatakan valid jika pertanyaan pada kuisioner mampu untuk mengungkapkan sesuatu yang akan diukur oleh kuisioner tersebut (Ghozali, 2011). Selanjutnya untuk mengetahui apakah suatu item valid atau gugur maka dilakukan pembandingan antara koefisien $t$ hitung dengan koefisien $\mathrm{t}$ tabel.Jika $\mathrm{t}$ hitung $>\mathrm{t}$ tabel berarti item valid.Sebaliknya jika $t$ hitung $<\mathrm{t}$ tabel berarti item tidak valid (gugur).

\section{Uji Asumsi Klasik \\ Uji Normalitas, Multikolonieritas, Heteroskedastisitas}

Uji Normalitas bertujuan untuk menguji apakah dalam model persamaan penelitian, variabel pengganggu atau residual memiliki distribusi normal. Cara mendeteksi dengan melihat normal probability plot adalah jika data menyebar di sekitar garis diagonal dan mengikuti arah garis diagonal atau grafik histogramnya menunjukkan pola distribusi normal, maka model persamaan penelitian memenuhi asumsi normalitas. normal, maka model persamaan penelitian tidak memenuhi asumsi normalitas.

Uji multikolonieritas bertujuan untuk menguji apakah dalam model persamaan penelitian ditemukan adanya korelasi antar variabel bebas (independen). Model persamaan penelitian yang baik seharusnya tidak terjadi korelasi di antara variabel bebas. Ada atau tidaknya multikolonieritas dapat dilihat dari Variance Inflation Factor (VIP). Jika nilai VIF tidak lebih dari 10 dan nilai Tolerance tidak kurang dari 0,1 maka model dapat dikatakan dapat dikatakan terbebas dari multikolonieritas (Ghozali, 2011).
Uji heteroskedastisitas bertujuan menguji apakah dalam model persamaan penelitian terjadi ketidaksamaan variance dari residual saat pengamatan ke pengamatan yang lain. Uji Heteroskedastisitas dengan cara melihat ada tidaknya pola tertentu pada grafik Scatter Plot. Penelitian yang baik adalah titik-titik menyebar diatas dan dibawah angka 0 dan tidak membentuk pola tertentu.

\section{Uji Analisi Regresi Berganda}

Dalam penelitian ini ,peneliti menggunakan alat uji analisis statistik. Untuk membuktikan hipotesis digunakan alat uji statistik regresi linier berganda (multiple linear regression).

Model yang digunakan dalam penelitian iniadalah:

$Y=\beta_{0}+\beta_{1} X_{1}+\beta_{2} X_{2}+\beta_{3} X_{3}+e$

Keterangan :

$$
\begin{aligned}
& \mathrm{Y}=\text { Kepatuhan masyarakat } \\
& \mathrm{X}_{1}=\text { Pengetahuan } \\
& \mathrm{X}_{2}=\text { Pendidikan } \\
& \mathrm{X}_{3}=\text { Sanksi Administrasi } \\
& 0=\text { konstanta } \\
& \mathrm{e}=3=\text { Koefisien regresi } \\
& \mathrm{e}=\text { error term }
\end{aligned}
$$

\section{Uji Hipotesis}

\section{Koefesien Determinasi}

Uji $\mathrm{R}^{2}$ berguna untuk mengukur besarnya sumbangan variabel bebas secara keseluruhan terhadap variabel terikatnya. $R^{2}$ memiliki nilai antara 0 dan $1 \quad\left(0<\mathrm{R}^{2}<1\right)$, dimana bila makin tinggi nilai $\mathrm{R}^{2}$ suatu regresi tersentu akan semakin baik. Berarti keseluruhan variabel bebas secara bersamasama mampu menerangkan variabel terikat.Sebelum diuji persamaan regresi berganda sesuai dengan pengujian secara simultan dan parsial, maka dilihat dahulu apakah persamaan yang telah dibuat diasumsikan tidak terjadi pengaruh antar variabel bebas.

\section{Uji Signifikan Simultan (Uji Statistik F )}

Uji $F$ digunakan untuk mengetahui seberapa besar pengaruh semua variabel independen terhadap variabel dependen. Pengujian dilakukan dengan 
membandingkan nilai $\mathrm{F}$ hitung dengan nilai $\mathrm{F}$ tabel, apabila nilai $\mathrm{F}$ hitung lebih besar daripada $\mathrm{F}$ tabel dengan tingkat signifikansi kurang dari 0,05 maka model yang digunakan layak, demikian pula sebaliknya (Ghozali, 2011).

\section{Uji Signifikan Parameter individual (Uji Statistik t)}

Uji $t$ merupakan pengujian hipotesis yang bertujuan untuk mengetahui besarnya pengaruh masing-masing variabel independen secara individual (parsial) terhadap variabl dependen. Kriteria pengujian yang digunakan adalah dengan membandingkan $t$ hitung dengan $t$ tabel jika t-hitung > t-tabel dengan tingkat signifikansi di bawah 0,05. Jika nilai signifikan dibawah 0,05 maka H0 ditolak dan Ha diterima (Ghozali, 2011).

\section{HASIL DAN PEMBAHASAN Uji Reliabilitas dan uji validitas}

Uji reliabilitas yang dilakukan pada penelitian ini menunjukkan seluruh variabel dinyatakan reliabel karena nilai Cronbach Alpha > 0,60 masing-masing 0,706, 0,618, $0,639, \quad 0,721$. Sedangkan pengujian validitas menyatakan bahwa semua item kuesioner dinyatakan valid karena semua nilai $\mathrm{t}$ hitung $>$ nilai $\mathrm{t}$ tabel.

\section{Uji Asumsi Klasik}

\section{Uji Normalitas, Multikolonieritas,}

\section{Heteroskedastisitas}

Metode yang digunakan untuk menguji normalitas adalah dengan melihat PP plot standardized residual. Dari hasil pengujian dapat dilihat bahwa data menyebar di sekitar garis diagonal dan mengikuti arah garis diagonal dan. Berdasarkan hal tersebut maka disimpulkan bahwa data terdistribusi normal.

Dari hasil Uji Multikolonieritas menunjukkan nilai Tolerance value semua variabel berada di atas 0,10 yaitu masingmasing sebesar 0,827, 0,935 dan 0,791 dan nilai Variance Inflation Factors (VIF) di bawah 10 yaitu masing-masing sebesar $1,029,1,070,1,264$. Dari hasil pengujian dapat disimpulkan bahwa tidak terjadi multikolinieritas dalam persamaan regresi.

Metode analisis yang digunakan untuk menguji heteroskedastisitas dengan melihat ada tidaknya pola tertentu pada grafik Scatter Plot. Hasil pengujian dapat dilihat bahwa titik-titik menyebar diatas dan dibawah angaka nol (0) pada sumbu Y dan tidak membentuk pola tertentu. Berdasarkan hal tersebut maka disimpulkan bahwa tidak terjadi Heteroskedastisitas pada model persamaan regresi .

\section{Uji Analisi Regresi Berganda}

Hasil analisis regresi dangan program SPSS 16 dapat dilihat pada tabel berikut :

Tabel 1

Coefficients $^{\mathrm{a}}$

\begin{tabular}{clccccc}
\hline & \multicolumn{7}{c}{$\begin{array}{c}\text { Unstandardized } \\
\text { Coefficients }\end{array}$} & \multicolumn{2}{c}{$\begin{array}{c}\text { Standardized } \\
\text { Coefficients }\end{array}$} & \\
& Model & B & Std. Error & Beta & T & Sig. \\
\hline 1 & (Constant) & -6.055 & 4.046 & & -1.497 & .139 \\
& Pengetahuan & .860 & .141 & .533 & 6.079 & .000 \\
& Pendidikan & .126 & .111 & .094 & 1.138 & .259 \\
& Sanksiadm & .277 & .091 & .274 & 3.049 & .003 \\
\hline
\end{tabular}

a. Dependent Variable: Kepatuhan

Sumber: Data Primer Diolah 2014

Dari analisis regresi didapatkan persamaan:

$Y=-6,055+0,860 X_{1}+0,126 X_{2}+$ $0,277 X_{3}+e$
Jika pengetahuan perpajakan, pendidikan dan sanksi administrasi konstan sama dengan nol (0), maka besarnya tingkat kepatuhan 
pembayaran PBB sebesar -6,055 satuan. Jika terjadi peningkatan pengetahuan tentang perpajakan wajib pajak sebesar satu satuan, maka akan terjadi peningkatan kepatuhan membayar pajak sebesar 0,860 satuan. Apabila terjadi peningkatan pendidikan $\left(\mathrm{X}_{2}\right)$ wajib pajak sebesar satu satuan, maka kepatuhan membayar pajak juga akan meningkat sebesar 0,126 satuan. Jika terjadi peningkatan sanksi administrasi sebesar satu satuan, maka akan meningkatkan kepatuhan pembayaran PBB sebesar 0,277 satuan.

\section{Koefisien Determinasi}

Pengujian Koefisien Determinasi dianalisis dengan melihat kolom Adjusted R Square pada tabel Model Summary. Nilai Adjusted R square sebesar 0,497 atau sebesar 49,7\%. Hal ini menunjukkan bahwa variabel dependen kepatuhan pembayaran PBB dipengaruhi oleh variabel independen pengetahuan perpajakan, pendidikan dan sanksi administrasi sebesar 49,7 \%. Sedangkan sisanya sebesar 50,3 \% dipengaruhi oleh variabel lain diluar penelitian ini.

Tabel 2

Model Summary ${ }^{\text {b }}$

\begin{tabular}{ccccc}
\hline Model & R & R Square & Adjusted R Square & Std. Error of the Estimate \\
\hline 1 & $.719^{\mathrm{a}}$ & .516 & .497 & 1.44476 \\
\hline
\end{tabular}

a. Predictors: (Constant), SanksiAdm, Pengetahuan, Pendidikan

b. Dependent Variable: Kepatuhan

Sumber :Data Primer Diolah 2014

\section{Uji Signifikan Simultan (Uji Statistik F )}

Hasil pengujian $\mathrm{F}$ dapat dilihat pada tabel

ANOVA berikut:

Tabel 3

ANOVA $^{\text {b }}$

\begin{tabular}{lccccc}
\hline \multicolumn{1}{c}{ Model } & $\begin{array}{c}\text { Sum of } \\
\text { Squares }\end{array}$ & Df & $\begin{array}{c}\text { Mean } \\
\text { Square }\end{array}$ & F & Sig. \\
\hline 1 Regression & 169.351 & 3 & 56.450 & 27.044 & $.000^{\mathrm{a}}$ \\
Residual & 158.637 & 76 & 2.087 & & \\
Total & 327.988 & 79 & & & \\
\hline
\end{tabular}

a. Predictors: (Constant), Sanksiadm, Pendidikan,Pengetahuan

b. Dependent Variable: Kepatuhan

Sumber :Data Primer Diolah 2014

Hasil uji $\mathrm{F}$ menunjukkan nilai $\mathrm{F}$ hitung sebesar 27,044, hal ini berarti $\mathrm{F}$ hitung $>\mathrm{F}$ tabel $(27,044>2,72)$, dengan tingkat signifikan 0,000 lebih kecil dari 0,05 (0,000 $<0,050)$. Maka dapat diambil kesimpulan bahwa Ho ditolak dan Ha diterima artinya bahwa variabel pengetahuan perpajakan, pendidikan dan sanksi administrasi bersama- sama mampu mempengaruhi variabel dependen kepatuhan pembayaran PBB.

\section{Uji Signifikan Parameter individual (Uji Statistik t)}

Berdasarkan uji $\mathrm{t}$ yang dilakukan dapat dilihat pada tabel berikut : 
Tabel 4

Coefficients $^{\mathrm{a}}$

\begin{tabular}{ccccccc}
\hline & \multicolumn{7}{c}{$\begin{array}{c}\text { Unstandardized } \\
\text { Coefficients }\end{array}$} & $\begin{array}{c}\text { Standardized } \\
\text { Coefficients }\end{array}$ & & \\
& Model & B & Std. Error & Beta & T & Sig. \\
\hline 1 & (Constant) & -6.055 & 4.046 & & -1.497 & .139 \\
& Pengetahuan & .860 & .141 & .533 & 6.079 & .000 \\
& Pendidikan & .126 & .111 & .094 & 1.138 & .259 \\
& Sanksiadm & .277 & .091 & .274 & 3.049 & .003 \\
\hline
\end{tabular}

a. Dependent Variable: Kepatuhan

Sumber :Data Primer Diolah 2014

Pengetahuan perpajakan memiliki nilai $\mathrm{t}$ hitung $>\mathrm{t}$ tabel $(6,079>1,665)$, tingkat signifikan sebesar 0,000 lebih kecil dari 0,05 . Hal ini berarti pengetahuan perpajakan secara signifikan mampu mempengaruhi kepatuhan pembayaran PBB. Hasil ini konsisten dengan penelitian yang dilakukan oleh Istanto (2010), Saryadi (2013), sutari (2013). Penelitian ini menunjukkan angka positif yang berarti bahwa semakin tinggi pengetahuan wajib pajak terhadap dunia perpajakan maka semakin tinggi pula kepatuhan wajib pajak dalam membayarkan PBB di Kabupaten Sleman.

Pendidikan memiliki nilai t hitung lebih kecil dari $\mathrm{t}$ tabel $(1,138<1,665)$, tingkat signifikan sebesar 0,259 lebih besar dari 0,05 . Hal ini berarti variabel pendidikan $\left(\mathrm{X}_{2}\right)$ tidak berpengaruh terhadap kepatuhan pembayaran PBB. Hasil ini konsisten dengan penelitian yang dilakukan oleh Dianawati (2008), Istanto (2010) dan Nurseto (2002). Variabel pendidikan tidak berpengaruh terhadap kepatuhan dikarenakan wajib pajak yang berpendidikan SD pun sudah mampu untuk memenuhi kewajiban untuk membayar Pajak Bumi dan Bangunan jika pemerintah setempat memberikan sosialisasi dan pengertian tentang arti penting pajak dan kewajiban sebagai wajib pajak. Kontrol yang baik dan sosialisasi dari pemerintah maupun aparat desa sudah mampu untuk memberikan informasi yang cukup wajib pajak pembayaran pajak. Sanksi administrasi memiliki nilai $\mathrm{t}$ hitung $>\mathrm{t}$ tabel $(3,049>1,665)$, tingkat signifikan sebesar 0,003 lebih kecil 0,05 . Hal ini berarti variabel sanksi administrasi $\left(\mathrm{X}_{3}\right)$ berpengaruh signifikan positif terhadap kepatuhan pembayaran PBB di Kabupaten Sleman. Hasil ini konsisten dengan penelitian yang dilakukan oleh Istanto (2010), Sutari (2013) dan Sapriadi (2013).

\section{SIMPULAN}

1. Berdasarkan hasil Uji t menunjukkan bahwa variabel pengetahuan perpajakan secara signifikan mampu mempengaruhi kepatuhan pembayaran PBB di Kabupaten Sleman.

2. Variabel pendidikan secara parsial tidak berpengaruh terhadap kepatuhan pembayaran PBB di Kabupaten Sleman.

3. Variabel sanksi administrasi secara parsial berpengaruh signifikan terhadap kepatuhan pembayaran PBB di kabupaten Sleman.

4. Berdasarkan hasil Uji $\mathrm{F}$ menunjukkan bahwa pengetahuan perpajakan, pendidikan dan sanksi administrasi secara bersama-sama (simultan) mampu mempengaruhi kepatuhan pembayaran PBB. Variabel yang paling bepengaruh terhadap kepatuhan adalah pengetahuan perpajakan.

5. Hasil Uji Regresi menunjukkan bahwa nilai Adjusted R square sebesar 0,497. Hal ini berarti kemampuan persamaan regresi pada penelitian ini menjelaskan variabel independen terhadap variabel dependen sebesar $49,7 \%$. Sedangkan 
$50,3 \%$ dijelaskan oleh faktor lain diluar penelitian ini.

\section{REFERENSI}

Dianawati, Susi . 2008.Analisis Pengaruh motivasi dan tingkat pendidikan terhadap kepatuhan Wajib Pajak. Skripsi.Jakarta

Ghozali, Imam. 2011. Aplikasi Analisis Multivariate dengan Program IBM.

Semarang: Badan Penerbit, UNDIP. Istanto,Fery . 2010. Analisis pengaruh pengetahuan tentang pajak, kualitas pelayanan

pajak, ketegasan sanksi perpajakan dan tingkat pendidikan terhadap motivasi wajib pajak dalam membayar pajak. Skripsi.Universitas Islam Negeri Syarif Hidayatullah .Jakarta

Mardiasmo.2011.Perpajakan.

Edisi

Revisi.Yogyakarta: ANDI

Nurseto, Cahyo. 2002. Pengaruh Persepsi tentang Pajak dan Tingkat
Pendidikan terhadap Kesadaran Wajib Pajak. STAN. Jakarta

Peraturan Daerah Kabupaten Sleman Nomor 11 tahun 2012 tentang Pajak Bumi dan Bangunan

Supriyati.2007.Pengaruh Pengetahuan Pajak dan Persepsi Wajib\Pajak Terhadap Kepatuhan WajibPajak.Jurnal Akuntansi dan Teknologi Informasi, Vol. 7, No. 1, hal 41-50.

Sapriadi,Doni. 2013. Pengaruh kualitas pelayanan pajak, sanksi pajak dan kesadaran wajib pajak terhadap kepatuhan wajib pajak dalam membayar PBB. Skripsi.Padang.

Sutari. 2013. Analisis Faktor-Faktor Yang Mempengaruhi Kemauan

Membayar Pajak Wajib Pajak Orang Pribadi.Skripsi.Yogyakarta.

Tjahjono, Achmad dan Muhammad Fakhri Husein. 2011. Perpajakan. Yogyakarta: UPP AMP YKPN. 